\title{
Cordelia Heß 6 Jews and the Black Death in Fourteenth-
Century Prussia: A Search for Traces
}

"For the Eastern European Jewry [Ostjudentum, from Poland and Lithuania] Prussia was, thanks to the policy of the Teutonic Order, not a gateway, but a bulwark restricting their influx."1

There is plenty of reason to doubt this assessment by Kurt Forstreuter, who was a historian and archivist in Königsberg (Kaliningrad) until 1943, and who was actively involved in stealing Jewish archives in the German-occupied territories in the East. ${ }^{2}$ But despite the political bias in his research regarding Jews and the contested rhetoric of "bulwarks", ${ }^{3}$ he highlights the one true problem: Why did Jews not settle in medieval Prussia and Livonia in the same way as they did in the surrounding areas, in Poland and Lithuania?

By the beginning of the sixteenth century, Jews had settled and were paying taxes in numerous places surrounding the Teutonic Order's territory - in Grodno, Vilnius and Troki, as well as in Łomża, Bydgoszcz and Płock. ${ }^{4}$ But in the case of Prussia and Livonia, we lack information about similar settlements and communities. It is not only in the antisemitic and völkisch German scholarship before and after the Second World War that one finds the presumption that this absence is the result of an active anti-Jewish policy on the part of the Teutonic Order. For example, nineteenth-century Jewish authors also believed medieval Prussia to be a place hostile to Jews. ${ }^{5}$ However, a closer look at the sources allows for a different interpretation. No anti-Jewish regulations were issued on behalf of the large Prussian towns before the middle of the fifteenth century, in connection with the Thirteen Years War, at which point they were issued by the Polish king at the request of the towns. The one possible antiJewish regulation issued by the Teutonic Order has not been preserved in a contemporary diplomatic form, but is only known from a contradictory tradition of chronicles composed about 150 years later - this phenomenon needs to be discussed in detail in another context. ${ }^{6}$ However, given the lack of evidence

\footnotetext{
1 Forstreuter 1937, 48.

2 On this part of Forstreuter's biography, see Heß 2014.

3 Examples in Burleigh 1984, 38-39.

4 Zaremska 2011, map 2.

5 Jolowicz 1867, 2-3.

6 See also the introduction to this volume.
} 
of a ban on Jewish settlement, the few sources regarding Jews in Prussia during the fourteenth century need to be reinvestigated.

Even those scholars who believe medieval Prussia to be entirely free of Jewish life - such as Forstreuter - have acknowledged evidence of Jews being named in Prussian sources in connection with the Black Death, which hit the region in 1350 and found its expression in contemporary historiography as well as in pragmatic sources such as town books. The fact that Jews are mentioned in this context allows for two differing assumptions: Either there were Jewish communities in Prussia around 1350, which fell victim to pogroms just like the Jewish communities all around Europe, or there were no Jewish communities, and in this case the transfer of the scapegoating of Jews for the pandemic is a peculiar case of absent presence. Before deciding upon one of these options, the sources need to be presented and discussed in detail. The time period for this event is especially interesting in the context since the presumed ban on Jewish settlement in Prussia is dated to the year 1309 - several decades before Prussian Jews were made responsible for the Black Death. This discrepancy has been noted by previous research but never been discussed in detail as part of a general assessment of potential traces of Jewish life in the region. ${ }^{7}$ The following article will discuss the remaining sources mentioning Jews in connection with the Black Death in Prussia around the year 1350 and examine closely the information they contain: Were there anti-Jewish pogroms in Prussia, and if yes, were they directed against local Jewish residents or against travellers? Did the information come from eye-witnesses, from other texts, or from hearsay? Can we assume that there were Jews in Prussia, just because they were blamed for the spreading of the pandemic?

The Black Death, and in particular, the pogroms and expulsions of Jews in the wake of the pandemic, were central events underlying major changes in the demographic structure of Jewish communities in Europe. ${ }^{8}$ The imagined connection of Jews to contagion in general, or more explicitly accusations of well-poisoning against Jews, was developed in southern Europe (France and the Iberian Peninsula) by the beginning of the fourteenth century, so by the time the plague reached the German lands and Poland, the scapegoating was well established in many places. ${ }^{9}$ The authorities moved quickly to gain control of what started as popular riots against the Jewish communities, staging trials

7 Forstreuter for example discusses some of the sources mentioning Prussian Jews and the Plague and simply concludes that they must have existed, and the pogroms as well. The contradiction to his assumption of an anti-Jewish ban remains unsolved.

8 Cohn 2002; Cluse 2002.

9 Ginzburg 1991; Stearns 2011, 54-65. 
against individuals, and forcing them to confess to conspiracies. Even in Northern Europe, in places less densely populated, and with fewer and smaller Jewish communities, pogroms triggered by the plague followed a common pattern: first tumultuous attacks, and then, after the summer of 1348, official trials. ${ }^{10}$

The source situation in Prussia is relatively good for the fourteenth century, even though quite specific and dominated by sources produced in connection with the landlords, the Teutonic Order and the bishops. Several chronicles in Latin and German cover the time period of interest here; the diplomatic tradition in the episcopates Warmia and Culm is relatively good for these years the Codex diplomaticus Warmiensis for example contains about 40 diploma for the years 1349-1350. The situation is somewhat less sufficient for the Prussian towns, in which the production of pragmatic and administrative texts only gained momentum in the last decades of the fourteenth century. Finally, Prussian events are mentioned in the historiographic production and political communication of the Hanseatic towns as well as the Polish realm.

Current research has questioned the nature and comprehensiveness of the diseases affecting Europe in the mid-fourteenth century. ${ }^{11}$ Regarding Prussia, the chronicles report major pestilentiae at least three times in this century, around 1320, around 1349, and in the 1380s - whether one or several of these actually report about outbreaks of the bubonic plague is of secondary importance in this context. Jews are mentioned only in connection with the disease during the years around 1349, with the narrative of a Jewish conspiracy against the Christians being repeated in several sources. But in fact, the Black Death takes a backseat in the chronicles to the descriptions of battles in the ongoing conflict with the Grand Duchy of Lithuania, especially in the lands of the Samogitians. Consequently, the chronicles - which for the most part are not contemporary, having been written at least a hundred years after the events - are contradictory regarding the evidence, chronology, and geographical range of the plague. Much of the historiographic tradition from sixteenth-century Danzig (Gdańsk) and Königsberg (Kaliningrad), which is partially based on the chronicle by Wigand of Marburg and partially on later sources, such as Simon Grunaus Preussische Chronik, makes no mention of the plague in the years 1348-1353. They focus instead on the wars and battles with the Lithuanians and on the warm winter of 1352, which made it impossible to cross the rivers; the Jubilee Year in Rome and the numerous pilgrimages it gave rise to are also

10 Müller 2002, 257.

11 Jankrift 2008. 
described, sometimes along with the 1384 pestilentia. ${ }^{12}$ The Chronicon Livoniae simply notes "Anno 1351 fuit maxima mortalitas [In the year of 1351, there was a great mortality]". ${ }^{13}$ More detailed accounts can be found in the chronicle by Lübeck Franciscan Detmar (died c. 1395), which describes a large number of Prussian events during the years 1105-1395; and this is also one of the few accounts that mentions Jews in connection with the disease. It is worth mentioning that no similar connections were made in the Prussian chronicles regarding earlier or later epidemics. The chronicle by Jan Długosz, from nearby Poland, for example, mentions the Black Death in 1349, along with anti-Jewish violence in Poland and Alemania, but does not mention any Prussian towns among the locations of either the plague or the pogroms. ${ }^{14}$

Considering the broad historiographic tradition telling about the Black Death, the few cases in which chroniclers mention Jews must be seen as exceptional, especially since most of them were not produced in Prussia itself. The most comprehensive account stems from Lübeck chronicler Detmar. His accounts of scapegoating are insofar interesting as they also mention the plague in Prussia and anti-Jewish pogroms, but make no explicit connection. For the entire German Baltic coast area, very few pogroms from this period are reported, ${ }^{15}$ but still, Detmar blames the Jews for the pandemic.

\subsection{The Detmar Chronicle}

In 1385, two Lübeck city council members commissioned a chronicle, since the urban historiography had largely been laid waste since the Black Death. They chose a representative of the institution which was least hit by the pandemic the Lübeck Franciscans in the St. Catherine monastery had profited so greatly from the foundations they had received during the plague years that they were able to extend their church considerably in the years following the epidemic. The lesemester Detmar spent the following ten years with the compilation and composition of a town and world chronicle, stretching from 1101 until his life-

12 See, for example, Cronica des landes Bruthenia, ietzund Preusserlant. Geschrieben durch Casparum Bittander (1609) in Uppsala, University Library, H 153 fol., fol. 111 ${ }^{\text {r }}$; also Simon Grunaus Preussische Chronik, I (1876), 609.

13 Hermanni de Warthberge Chronicon Livoniae, 77.

14 Ioannis Dlugossii Annales, fol. 112 .

15 An exception is Königsberg in Neumark (Nova Marchia), where a pogrom took place in 1351. Cluse 2002, 240. 
time. The Black Death is described in several paragraphs in one version of Detmar's chronicle, the one used by the Lübeck city council. ${ }^{16}$ He mentions 1346 as the year of the first outbreak of the pandemic, describing the spread of the disease from the Holy Land, where it had killed thousands of heathens, "which was not much to moan about, since they are the enemies of God", thereafter spreading to Christian lands, such as Hungary, Italy and France, followed by England and Flanders, then, Sweden, Norway, Sealand (that is, Denmark), spreading from there to Prussia, especially Königsberg and Elbing (Elbląg). After providing this account of the contested regions, Detmar writes:

\begin{abstract}
Des tech men den ghedoften joden, de sik vor cristene lude helden unde beden vor Got ghuder lude almosen, dat de mit vorghifnisse, de se den luden gheven, das volk to deme dode brochten. Dat wart van en gheseen unde worden anghetastet unde worden ghebrand; do bekande se in erme dode, dat is war were, dat se it hadden ghedan, unde dat ir vele were, de in der selven sake in der cristenheit ghinghen, unde segheden, dat de riken joden in den groten steden dat bedacht hedden der cristenheit to vorderfnisse, wente se sint der martere unses heren ghevanghen lude hebben wesen, unde wolden nue koninghe unde heren worden sin over al den cristendom. ${ }^{17}$
\end{abstract}

[The baptized Jews, who pretend to be Christian people and beg for God's and good people's alms, were held responsible for killing the population with poison which they gave the people. They were seen doing this and were attacked and burned; and in their death they confessed that this was true, that they had done it, and that they were many who were walking among the Christians in the same matter, and they said that the rich Jews in the towns had thought this out in order to destroy Christianity, because they have been prisoners ever since the torture of our Lord and now they want to become kings and lords over all of Christianity.]

A second occurrence of the Black Death in 1348 is mentioned in the Detmar Chronicle, and here an astronomer's explanation of the disease as the result of a particular constellation of planets in 1345 is recounted, even though Detmar himself does not believe the stars to be responsible for anything, being nothing more than signs of things to come. He does not directly blame the Jews for the plague, but:

$\mathrm{Nu}$ hadden ok de joden grote mestere in der sulven kunst astronomia, de langhe vorgheseen hadden de tid des stervendes. Do ghewunnen de joden arghe danken, unde wurden des to rade, dat se mit vorghifnisse hemeliker sake unde mit arghen dinghen tolegheden unde hulpen desseme vorbenomenden tokomenden stervende, uppe dat se dar nicht ane vordracht worden unde wolden sik vryen van der eghenschap, dar se inne syn. Nu wolde

16 The version from Stadtbibliothek Lübeck is believed to be the copy in use at the Lübeck city council.

17 Detmar-Chronik, 505. 
Ghod, dat dit to wetende wart den mechtighen heren in den landen unde den guden steden, de worden des to rade, dat se de undat wreken wolden an den joden unde sloghen se in manghen landen unde in menigher stat to dode. ${ }^{18}$

[The Jews also had great masters in the very art of astronomy, who a long time ago had already foreseen the time of the dying. Thus, the Jews had evil thoughts, and decided that they wanted to help this aforementioned dying which was to come by means of secret planning and the addition of bad things, so that they could not be held responsible for this and would free themselves from the state of being owned that they are in. But God wanted this to become known to the powerful lords in the lands and the good towns, who decided to punish the Jews for the misdeeds and killed them in many countries and in many towns.]

To sum up, the Detmar Chronicle placed some emphasis on a disease that was supposedly the Black Death, which occurred between 1346 and 1350. Detmar has an informed view of the geographical origin and spread of the pandemic and discusses different explanations, for example, mankind's sinful state, stellar constellations, and the Jews. On two occasions, Detmar explicitly identifies Jews to be punished in connection with the disease. He first mentions baptized Jews, who were said to have poisoned people, subsequently confessing under torture to propagating and spreading the disease. Their explanation was that they had been captives ever since they killed Jesus Christ, but were determined to become the kings of the world again. Two Prussian towns are explicitly mentioned in connection with disease, but the location of the trials of the converts is never identified.

In the second case, the disease "in the German lands" is linked to a conspiracy of Jewish astronomers to take advantage of the disease and exacerbate the dying. In both cases, evidence of the Jews' guilt came from their own accounts during trials and under torture. Furthermore, in both cases, the control and "ownership" of the Jews by Christians is the reason offered for their hatred of Christians.

Detmar's descriptions of the alleged Jewish conspiracies related to the Black Death are not particularly detailed. For example, the common accusation of poisoning wells and water is not mentioned, no details are provided about the form and preparation of the poison, and so on, and no location of the trials and confessions is offered. This makes it unlikely that Detmar possessed actual copies of trial documents, from which he was directly quoting, as was the case in the south of France, where summaries of trials were copied and sent to other towns, becoming models for chroniclers' accounts of the events. ${ }^{19}$ Consequent-

18 Detmar-Chronik, 514.

19 Ginzburg 1991, 68. 
ly, this source provides no useful information about anti-Jewish pogroms - and thereby the existence of Jews - in the northern German lands and Prussia. Nonetheless, the Black Death plays a prominent role in the chronicle, which otherwise has a very strong local focus on the Hanseatic towns along the Baltic Sea coast. Although there were no major Jewish communities in most of these locations, in the Detmar chronicle, the connection between Jews and the disease is very marked. Both the poisoning theory and the astronomical explanation are connected to a Jewish conspiracy. A possible explanation for this, considering the lack of Jewish communities in most of the locations Detmar mentions, would be spontaneous pogroms against Jews who were in the towns as travellers or guests - or against Jewish converts, as previously mentioned. Later sources do provide evidence that Jewish converts lived in some of the Prussian towns.

\subsection{The Chronicon Olivense}

A similar connection between the Black Death in Prussia and Jews is made in a chronicle originating in Prussia itself, the Chronicon Olivense or Older Chronicle of Oliva, written in 1351 by a Cistercian monk at the Oliva monastery close to Gdańsk. While the chronicle relies primarily on older sources, such as Peter of Dusburg, the account of the Prussian plague is original and has no parallel tradition. ${ }^{20}$

The Chronicon Olivense - putting even more emphasis on the account of the disease than Detmar had - dates the plague to 1351 and mentions its origin in India, with an apocalyptic course of events: bad air, horrible sounds, and fire and mist descending from the sky, infecting and killing the people. The chronicle claims that physicians in Italy distinguished three different kinds of disease. It also provides a detailed description of the measures taken against the plague in Avignon and Marseille, as well as the processions of the flagel-

20 The Chronicle of Oliva was edited twice, first in Scriptores rerum Prussicarum (SRP) I, 1861, $653 \mathrm{ff}$., and then, after several new manuscripts were found, in SRP v, 1874, $594 \mathrm{ff}$. One of the major differences between these two editions is the lengthy paragraph about the Black Death, which was only found in what is probably the oldest remaining manuscript, dating to the fifteenth century, and held by a library in Lviv. Max Perlbach, whose investigation of the chronicle remains the most comprehensive study of the text, had worked with a much younger manuscript version, and thus did not comment on this episode - which, not least of all, changed the dating of the chronicle from 1348 to 1351. Hirsch 1874; Perlbach 1871; Perlbach 1872. 
lants. The chronicle seems to draw information from different clerical sources, probably itinerant members of the Cistercian Order, who had themselves experienced the disease in the south, or letters circulating in the Cistercian monasteries. However, even in the more learned and detailed account found in the Chronicon Olivense, the blame placed on the Jews and the punishment meted out was central to the description of the disease in Prussia and Pomerania, although it nowhere explicitly mentions Jews being killed there.

Predicta ergo pestilencia [...] iam fere in tota Pruzia et Pomerania innumerabiles viros ac mulieres consumpsit et hodierna die consumere non cessat. Et quod est miserabilius istis epydimijs et pestilencijs immiscuit se odium Iudeorum [...] per nuncios suos Iudeos occultos et per malos Christianos, quos ad hoc faciendum peccunia corruperunt per totam Germaniam et Poloniam, ut inficerent fontes et flumina, de quibus Christiani deberent coquere cibos suos [...] et propter hoc omnes Iudei in tota Germania et Alemania et fere in tota Polonia sunt deleti, alij gladijs occisi, alij in igne cremanti, et alij in aquis suffocati, et multi mali Christiani [...] postquam receperant a Iudeis peccunias, Iudei per quedam dyabolica verba, que ipsis in aures susurrauerunt, adeo ipsos dementauerunt et in odium Christianorum accenderunt, quod si potuisssent uno actu totam Christianitatem libenter deleuissent. ${ }^{21}$

[The aforementioned plague ... has already killed innumerable men and women in Prussia and Pomerania and has until today not stopped killing. And what is even worse is that these epidemics and plagues have been sent here by the Jews' hatred ... by their messengers, the secret Jews and the bad Christians, who have received money throughout Germany and Poland for doing this, so as to infect wells and rivers, from which the Christians had to prepare their food ... and because of this all Jews in all Germania and Alemania and also in all of Poland are annihilated, many killed by the sword, others burned in fire, and others drowned in water, and many bad Christians ... after they had received money from Jews, the Jews had deluded them with certain devilish words which they whispered in their ears, so that they were inflamed with hatred of the Christians so that they would gladly destroy all Christianity in one act.]

Here as well, Prussia is specifically mentioned as a place hit hard by the plague, and again, the Jews are immediately blamed, along with "bad Christians." The account of the disease's spread is more detailed than in the Detmar Chronicle, with also the anti-Jewish pogroms described in great detail - no trials are mentioned, however. The description seems to be a synopsis of various accounts the author has heard or read, and from which he draws the information most important to him. Again, the "secret" Jews, that is, those who only superficially accepted baptism, are held responsible along with those who remained Jewish. The Jews are identified as entirely separate from the Christian

21 Chronicon Olivense, 621-622. 
communities - they poison the water the Christians have to use - and special emphasis is put on the different ways they were killed, suggesting both spontaneous pogroms and death penalties issued at trials.

The fact that the author of the Chronicon Olivense lived during the pandemic and was an inhabitant of Prussia gives this account a certain authority regarding the lack of evidence of pogroms in Prussia, which he mentions as hard hit by the plague, but not as a site of anti-Jewish violence.

\subsection{Letters from Lübeck and Visby}

The third relevant source regarding anti-Jewish violence in Prussia in the 1350s is a letter from the Lübeck town council to Duke Otto of Lüneburg. ${ }^{22}$ There is no actual date on the letter itself, but it has been placed within the context of the Black Death in the Baltic Sea region and dated to 1350. The council members from Lübeck tell the Duke about the trial of a certain Keyenort, who was burned at the stake in Lübeck, and about a woman who prepared poison from snakes she kept in her house. No Jews are mentioned in connection with the woman, but Keyenort confessed to receiving three solidi from the Jews to poison people from Prussia to Lübeck on their behalf - no mention is made of the location of the trial. The men from Lübeck write that also council members from Rostock and other Hanseatic cities had reported Jews confessing to poisonings in their cities and in "the Slavic countries." The same letter also quotes yet another letter from the council of Visby, describing the trial of a certain Tidericus, who was burned after having confessed to receiving money and poison from a Jew named Aaron, son of Solomon, in Hannover, and having used it to poison numerous wells and fountains in a number of towns in Hannover county. While he was gambling with his blood money in Lübeck, Tidericus was approached by another Jew, named Moyses, who gave him more money. As a result, he travelled to Prussia, specifically Frauenburg (Frombork), and killed forty people, and a further forty in Memel (Klaipèda), Hasenpoth (Aizpute), Goldingen (Kuldiga), Pilten (Piltene), and Windau (Ventspils), before travelling on to Curland.23 The council members add a few short lines of particular interest regarding Prussia:

\section{UB Lübeck III, 105.}

23 Cod. dipl. Warm. III, 1874, no. 633, 634 quotes the letter incorrectly, mixing together the trials in Lübeck and Visby. The full text of the letter is printed in UB Lübeck III, 104, no. 110 A. Ibid. no. 110 B, 105-106, contains a different letter that also mentions the Visby trial. This 
Eciam consules Thurunenses scripserunt nobis de pluribus Judeis baptizatis in civitate eorum deprehensis, et omnes recognovissent, quod huiusmodi operacio intoxicacionis totaliter a Judeis ortum habet processum. ${ }^{24}$

[The council members of Thorn (Toruń) also wrote to us about many baptized Jews who were caught in their town, and they all remembered that the trial had its origin in this mode of total intoxication by the Jews.]

This otherwise mysterious sentence at least proves the existence of baptized Jews in Thorn and their persecution, although in a very vague way - were the council members recalling a concrete trial against the baptized Jews of Thorn or another trial? When did it take place?

The letter from Visby has also been preserved, and it tells a somewhat different story from the Lübeck letter. ${ }^{25}$ Two people who made poison were burned at the stake. They had confessed to poisoning numerous people in different Swedish towns and of plans to poison all of Gotland. They claimed to belong to a secret society of Jews and bad Christians intent upon poisoning all of Christianity. Just before being burnt at the stake, one of them said: "Nescio plura vobis dicere, sed tota Christianitas est per Judæos et pessimos nos intoxicata [I do not know more things to tell you, but all of Christianity is poisoned by the Jews and by the worst of us]". Both of the letters from Lübeck and Visby to the Duke end with the demand that the Jews be deprived of privileges and protection in order to ensure that they are found and punished for their evil deeds.

All of these letters are undated, but have been connected to the Black Death that occurred around 1350 in the source editions and in subsequent scholarly research. The method of killing, in particular, that is well-poisoning, is reminiscent of the accusations in the wake of the Black Death, even though the number of victims seems relatively small considering the number of fatalities during the pandemic. The letters may also refer to events that occurred either before or after the Black Death, since they are full of hearsay and references to other people having told other stories or written other letters - however, the connection of Jews to bad Christians, who are misled into killing by the former, a high number of casualties due to poisoned wells, and the vast geographical range of the casualties due to the work of a travelling killer, are all familiar elements from the anti-Jewish accusations connected to the Black

letter resembles more closely the actual letter preserved from Visby, which was sent by the council of Rostock to the Duke of Mecklenburg.

24 UB Lübeck III, 105.

25 SDHK no. 5883, DS no. 4665; UB Lübeck III, 105; UB Mecklenburg X, no. 7083. 
Death. Lübeck and Visby present similar accounts of Jewish settlement in Prussian and most of the Hanseatic towns - there is no sign of stable communities, but there is also no evidence of major conflicts or anti-Jewish regulations. of course, it is very likely that Jews were present in the town as travellers, guests, and temporary residents. Three letters that were circulating in the Hanseatic towns on the Baltic coast around the same time reported trials against and death penalties for Jews or people who confessed to have been paid by Jews, and these letters asserted that these persons had travelled around Prussia. This can be treated as relatively solid evidence that Jews were held responsible for the diseases in these areas as well. It is, however, remarkable that none of the trials was the result of the casualties in the town where the trial was held the accused in Lübeck were punished for casualties in Prussia, and the accused in Visby for casualties elsewhere in Sweden and Prussia. The reference to baptized Jews put on trial in Thorn is vague. The Lübeck, Rostock and Visby council members seem to have had a clearer idea regarding the towns affected by the pandemic than about the whereabouts of the people condemned for spreading it - there is no mention in any of the letters of where the Jews came from, what their professions were, or where they lived.

\subsection{The Braunsberg liber civitatis}

A fourth account of somewhat mysterious origin adds to the impression that Jews were thought to be responsible for the Black Death in Prussia, but in this account, the suspicion is not said to have led to any sweeping persecution. It is undated and preserved in the oldest liber civitatis of Braunsberg (Braniewo).

Rumboldi memoria et malicia. Anno domini M.ccc.xl. nono a festo pasce vsque ad festum galli fuit in terra pruscie Rvmboldus Judeus qui dixit se esse baptizatum. Qui per intoxicaciones veneni et per incantaciones diuersas multos interfecit et precipue in Elbingo vbi a festo Bartholomei vsque ad nativitatem christi plus quam nouem Milia hominum veneno quasi morte subitanea interierunt. Item in eodem anno in Konigisberg multitudo hominum interiit non computata. Item in marienburg similiter. Item in hollandia. In heiligenbil. In vrowinborg. In Molhusin. Item in terra Sambye multi prutheni veneno perierunt. Eodem anno multi tam noxii quam inoxii propter venenum cremati sunt vndique terrarum. ${ }^{26}$

[About the memory and the bad deeds of Rumboldus. In the year of the Lord 1349 from Easter until St. Gallus, the Jew, Rumboldus, who claimed to be baptized, was in the land

26 Cod. dipl. Warm. II, 1864, 152. 
of Prussia. He killed many with poisoned drinks and different incantations, especially in Elbing, where more than nine thousand people died almost immediately of poisoning between St. Bartholomew's and Christ's Birth. Also in the same year in Königsberg a mass of people died, they were not counted. The same in Marienburg (Malbork). The same in Preußisch Holland (Pasłęk), in Heiligenbeil (Mamonovo), Frauenburg (Frombork), Mühlhausen (Młynary). Also in the land of Sambia many Prussians died of poisoning. In the same year many were burned in all countries because of the poisoning, guilty as well as innocent.]

This is the most comprehensive account of the spread of a disease in Prussia: It names more towns than any of the others, and includes Sambia, as well as providing precise dates, one for Rumboldus' sojourn in Prussia, and one for the fatalities in Königsberg. The dates partially overlap - Rumboldus is said to have travelled around Prussia between 12 April and 16 October, while people in Elbing are said to have died suddenly between 24 August and 25 December. This suggests that the effects of Rumboldus' poison and incantations remained effective even after he had left - or after he was killed. The report mentions people having been held responsible for the dying, but does not make explicit whether or not Rumboldus himself was punished by death at the stake. The report itself is preserved in the liber civitatis of Braunsberg, but Braunsberg is not among the many towns mentioned as having been hit by the poisoning.

Both the Detmar Chronicle and the anonymous report from the Braunsberg liber civitatis explicitly mention Königsberg and Elbing as suffering high levels of fatality; while the Chronicon Olivense names Prussia and Pomerania. Detmar dates the beginning of the disease in Prussia as 1346, the anonymous report as 1349, and the chronicle of Oliva claims it started in the Mediterranean in 1347, reaching Prussia in 1350, and continuing into 1351 when this part of the chronicle was written. The two chronicles are written shortly after the events themselves. This is also true for the letters from Visby and Lübeck, which were probably written in either the 1340 s or the 1350 s, but cannot be precisely dated.

\subsection{Jews in Prussia?}

Blaming Jewish converts is a recurrent feature in the reports. In the Detmar chronicle, they are said to be pretending to be Christians and living off their alms. Those accused of the poisonings are themselves obviously poor beggars and vagrants, and thereby, even without the Jewish ascription, belong to a marginalized group - a pattern similar to persecution in France, which started with paupers as victims, and subsequently Jews. ${ }^{27}$ The chronicle of Oliva

27 Ginzburg 1991, 65. 
names Iudaeos occultos (secret Jews), and in the case of Rumboldus, a traveller, or vagrant, is accused of the poisonings. In both cases, the accused are ascribed the status of Jews, although they claim to be Christian or are even living as converts, receiving alms as a result of their status - in the case of Prussia, there are several reports about the High Master himself, as well as the bishops of Sambia, providing converts and their families with monetary aid in order to prevent them from returning to the Jewish faith. ${ }^{28}$ The name Rumboldus points to the traveller being from either the Low Countries or England, where saints with this name were venerated. ${ }^{29}$ In the letters from Lübeck and Visby, on the other hand, "bad Christians" are blamed, and they claim to have been paid and misled by Jews to perform the deeds. In almost all of the sources, the terms "sorcery" and "witchcraft" are used: incantations, whispering words in someone's ear, secret things. Rumboldus is presented as a lone killer, while the other sources suggest a far-reaching Jewish conspiracy. Reasons for the crimes are, in the cases of the bad Christians, money and being bewitched, and in the case of the Jews and converts, hatred of Christians and the wish to enslave them under Jewish rule as revenge for their own present enslavement under Christian rule.

Samuel Cohn has pointed out the social circumstances of anti-Jewish violence during the plague years, most of which was staged by local authorities rather than being spontaneous outbreaks of hatred by the lower classes or peasants. ${ }^{30}$ In the Prussian sources, we learn little about the perpetrators - in Visby and Rostock, the urban authorities held the trials, but the accused were Christian foreigners, while in the chronicles, it is not possible to distinguish who killed the Jews. It seems to be obvious, though, that the accused were not well-off merchants, money-lenders, or physicians, but poor people living or travelling in the rural areas: The Detmar Chronicle refers to their confessions, in which they identify "the rich Jews in the towns" as the minds behind the conspiracy. Both the Jews and the Christians accused in the Prussian and Hanseatic sources were, as such, poor people and vagrants, and it is likely that this fact was actually the primary incentive for blaming them - the identification with the Jewish religion is very vague in most cases, suggesting that they were probably primarily perceived as social outsiders, not religious outsiders, and were persecuted during the Black Death for that reason, as is known from southern Europe. ${ }^{31}$

28 Cod. dipl. Warm. II (1864), 316-317; Marienburger Tresslerbuch, 501, 552.

29 Rumoldi (Rombaldi) ep. Dublinensis, venerated in the dioceses of Utrecht, Lüttich, and Exeter; Rumwoldi, venerated in England. Grotefend 1898.

30 Cohn 2007.

31 Cohn 2007, 9. 
Despite all of these sources being chronologically close to the events and considered to be of high historiographic reliability, they do not provide a consistent picture of the spread of the Black Death, particularly as only two of them were directly produced in Prussia, while the others derive from other Hanseatic towns. It is likely that the bubonic plague that hit large parts of Europe also reached Prussia by ship, and possibly also over land from Poland, sometime between 1347 and 1351. It is, however, not possible to connect all the sources mentioned clearly to this specific disease and its spread. There are other sources that also mention a pestilentia in these years, but they are all of much later origin, and, in any case, the information they contain about diseases in the years around 1386 and 1427 is much clearer than about the mortalities around 1350. The chronicle by Jan Długosz, from nearby Poland, for example, mentions the Black Death in 1349, along with anti-Jewish violence in Poland and Alemania, but does not mention any Prussian towns among the locations of either the plague or the pogroms. ${ }^{32}$ Since earlier scholars and editors of source collections felt more comfortable attributing different reports about diseases from the fourteenth century to the Black Death that occurred around 1350 than we are today, when we consider the state of the research, it is no longer possible to decide whether or not all these sources are addressing the same event. What is obvious, however, is that a number of fourteenth-century sources from Prussia and the Hanseatic towns in the Baltic coastal area connected epidemic diseases to Jews or Jewish converts to Christianity, even if these towns themselves were not party to any anti-Jewish pogroms. It is also obvious that they do not directly report anti-Jewish violence in Prussia during this period, although the Jews were blamed.

There are a number of ways to interpret this. The first one would see the emergence of Jews as scapegoats in Prussia and the Baltic as a sign of this area being a part of a general Christian-European cultural framework, in which antiJudaism was a formative element. The connection of Jews to sorcery, diseases, poisoning, and conspiracies is well established in the case of southern Europe and the German lands, both before and after the first wave of the bubonic plague, and to the Prussian chroniclers it probably did not seem to be farfetched to blame non-existing Jews for the fourteenth-century diseases - thus the focus on travellers and vagrants.

However, there is an alternative interpretation that does not presume that there were no Jews in Prussia, as blaming Jews for spreading diseases remains a sign of a shared European framework of anti-Jewish resentment. The focus on travellers and vagrants would suggest that there was no anti-Jewish violence

32 Ioannis Dlugossii Annales, fol. 112 ${ }^{\mathrm{r}}$. 
in the Prussian towns themselves, and that the persons blamed were generally victims or scapegoats because of their status as foreigners, not because they were non-Christian. Overall, the historiographic accounts that mention diseases in the fourteenth century without mentioning Jews by far outnumber the ones presented here that make the connection. During this period, the Teutonic Order and its chroniclers were preoccupied with the consolidation of their territory and the persistent conflicts with the neighbouring Lithuanians - and later, the Poles. After the initial task of Christianizing the Old Prussians was completed, expanding into Lithuanian territory became the primary goal of the Teutonic Order's warfare - and converting Lithuanians the primary objective of its propaganda. Although the Order and the literate Prussian elite - Cistercian monks from Oliva, German town scribes in Braunsberg - certainly shared a common Christian ideology that easily blamed Jews, but they themselves did not see any Jews burnt at the stake, and as the Teutonic Order itself was much more preoccupied with anti-Lithuanian warfare and anti-pagan propaganda, these chroniclers also did not put any particular emphasis on Jews being responsible for diseases. Prussia in the fourteenth century was probably not a good place to be a Jew - but there were much worse places, and there were definitely no good places to be a pagan, if we are to believe the propaganda. "Nur wenn es Streit gab, kam etwas in die Akten [only if there was a conflict, was a record written]" writes Kurt Forstreuter in a later version of his article about the Jews in Prussia. ${ }^{33}$ Here again, his conclusions are not the obvious ones - maybe the fact that there are very few conflicts reported between Jews and Christians in Prussia does not mean that there had never been any Jews in the country. Maybe the fact that we lack information about interreligious conflicts and anti-Jewish pogroms in Prussia before the fifteenth century simply means that there were no conflicts between the inhabitants who adhered to different monotheistic beliefs.

\section{Bibliography}

\section{Primary sources}

Chronicon Olivense $=$ Hirsch, Theodor (Ed.). Die Ältere Chronik und die Schrifttafeln von Oliva. SRP I (1861). 669-726.

Cod. dipl. Warm. = Codex Diplomaticus Warmiensis oder Regesten und Urkunden zur Geschichte Ermlands. 4 vols. Eds. Carl Peter Woelky and Johann Martin Saage. Mainz: Kirchheim: Braunsberg: Peter, 1860-1935.

33 Forstreuter 1981, 276. 
Cronica des landes Bruthenia, ietzund Preusserlant. Geschrieben durch Casparum Bittander

(1609). Uppsala, University Library, H 153 fol.

Detmar-Chronik = Koppmann, Karl (Ed.). Chroniken der deutschen Städte. Vol. 19. Detmar-

Chronik von 1105-1386. Leipzig: Hirzel, 1884. 187-596.

Hermanni de Warthberge Chronicon Livoniae = Strehlke, Ernst (Ed.). Hermanni de

Warthberge Chronicon Livoniae. SRP II (1863). 21-116.

loannis Dlugossii Annales = Dąbrowski, Jan (Ed.). Ioannis Dlugossii Annales seu cronicae

incliti regni Poloniae Liber IX. Warszawa: Państwowe Wydawnictwo Naukowe, 1978.

Marienburger Tresslerbuch = Joachim, Erich (Ed.). Das Marienburger Tresslerbuch der Jahre

1399-1409. Königsberg in Preussen: Thomas \& Oppermann, 1896.

SDHK = Svenskt Diplomatariums huvudkartotek över medeltidsbreven. 〈riksarkivet.se/sdhk >

Simon Grunaus Preussische Chronik. 3 vols. Eds. Max Perlbach, Rudolf Philippi, and Paul Wagner. Leipzig, 1876-1889.

$\mathrm{SRP}=$ Scriptores rerum Prussicarum. Die Geschichtsquellen der preussischen Vorzeit bis zum Untergange der Ordensherrschaft. 6 vols. I-v: Eds. Theodor Hirsch, Max Töppen, and Ernst Strehlke. Leipzig: Hirzel, 1861-1874; vI: Eds. Walther Hubatsch and Udo Arnold. Frankfurt am Main: Minerva-Verlag, 1968.

UB Lübeck: Urkundenbuch der Stadt Lübeck. Abth. 1: Codex diplomaticus Lubecensis. Theil 3: Urkunden bis 1350. Lübeck: Aschenfeldt, 1871.

UB Mecklenburg: Meklenburgisches Urkundenbuch. x: 1346-1350; Nachträge zu Band I-x. Schwerin: Stiller in Komm, 1877.

\section{Literature}

Burleigh, Michael. Prussian Society and the German Order: An Aristocratic Corporation in Crisis c. 1410-1466. Cambridge: Cambridge University Press, 1984.

Cluse, Christoph. "Zur Chronologie der Verfolgungen zur Zeit des 'Schwarzen Todes'." Geschichte der Juden im Mittelalter von der Nordsee bis zu den Südalpen:

Kommentiertes Kartenwerk. Ed. Alfred Haverkamp. Hannover: Hahnsche Buchhandlung, 2002. 223-242.

Cohn, Samuel K., Jr. “The Black Death: End of a Paradigm.” American Historical Review 107.3 (2002): 703-738.

Cohn, Samuel K. "The Black Death and the Burning of Jews." Past \& Present 196.1 (2007): 336.

Forstreuter, Kurt. “Die ersten Juden in Ostpreußen.” Altpreußische Forschungen 14 (1937): 42-48.

Forstreuter, Kurt. “Die Juden im Deutschordenslande Preußen.” Wirkungen des Preußenlandes: Vierzig Beiträge. Köln: Grote, 1981. 270-280.

Ginzburg, Carlo. Ecstasies: Deciphering the Witches' Sabbath. New York: Pantheon Books, 1991.

Grotefend, Hermann. Taschenbuch der Zeitrechnung des deutschen Mittelalters und der Neuzeit: Für den praktischen Gebrauch und zu Lehrzwecken entworfen. Hannover, Leipzig: Hahn, 1898. < http://www.manuscripta-mediaevalia.de/gaeste/grotefend/ titel.htm\#Zeitrechnung >

Heß, Cordelia. "'Some short business trips.' Kurt Forstreuter and the Looting of Archives in Poland and Lithuania, 1939-1942." Yad Vashem Studies 42.2 (2014): 91-122. 
Hirsch, Theodor. "Die ältere Chronik von Oliva. Einleitung.” SRP v (1874). 591-594.

Jankrift, Kay P. "The Language of Plague and its Regional Perspectives: The Case of Medieval Germany." Pestilential Complexities: Understanding Medieval Plague. Ed. Vivian Nutton. London: Wellcome Trust Centre for the History of Medicine at UCL, 2008. 53-58.

Jolowicz, Heimann. Geschichte der Juden in Königsberg in Preussen. Ein Beitrag zur Sittengeschichte des preussischen Staates. Posen: Jolowicz, 1867.

Müller, Jörg R. “Erez gezerah - 'Land of Persecution': Pogroms against the Jews in the Regnum Teutonicum from c. 1280 to 1350." The Jews of Europe in the Middle Ages (Tenth to Fifteenth Centuries): Proceedings of the International Symposium Held at Speyer, 2025 October 2002. Ed. Christoph Cluse. Turnhout: Brepols, 2004. 245-260.

Perlbach, Max. Die ältere Chronik von Oliva. Göttingen: Huth, 1871.

Perlbach, Max. "Über die Ergebnisse der Lemberger Handschrift für die ältere Chronik von Oliva." Altpreußische Monatsschrift 9 (1872): 18-40.

Stearns, Justin K. Infectious Ideas: Contagion in Premodern Islamic and Christian Thought in the Western Mediterranean. Baltimore: The Johns Hopkins University Press, 2011.

Zaremska, Hanna. Żydzi w średniowiecznej Polsce. Gmina Krakowska. Warszawa: Instytut Historii PAN, 2011. 
